\title{
Isolation and structure identification of new cytokinins from Gleditsia caspia
}

\author{
Mohammad Hosny, Ehab A. Ragab, Abd El-Salam I. Mohammed, and Usama Y. Shaheen* \\ Department of Pharmacognosy, Faculty of Pharmacy, Al-Azhar University, Cairo, Egypt \\ E-mail: usamayosef2003@yahoo.com
}

\begin{abstract}
Phytochemical investigation of the $n-\mathrm{BuOH}$ - soluble fraction of the alcoholic extract of the fruits of Gleditsia caspia (Leguminosae) resulted in the isolation and identification of three new cytokinin derivatives identified as 6- $N$-(3-methylbut-2-enylamino)-2-hydroxy-9- $\beta$-Dglucopyranosyl purine, 6- $N$-(cis-4-hydroxy-3-methylbut-2-enylamino)-2-hydroxy-9- $\beta$-Dglucopyranosyl purine, and 6- $N$-(3-methylbut-2-enylamino)-2-hydroxy-9-[ $\beta$-D-apiofuranosyl$\left(1^{\prime \prime} \rightarrow 6^{\prime}\right)-\beta$-D-glucopyranosyl] purine. The structures of the isolated compounds were established by $1 \mathrm{D}-\left({ }^{1} \mathrm{H}-,{ }^{13} \mathrm{C}\right.$ - and DEPT) and 2D- (COSY, HMQC and HMBC) NMR analysis.
\end{abstract}

Keywords: $N$-6-Substituted adenine derivatives, cytokinins, NMR, Gleditsia caspia

\section{Introduction}

Cytokinins are plant hormones which regulate plant cell proliferation. ${ }^{1}$ Most natural cytokinins are $N$-6- substituted adenine derivatives generated as degradation products during depurination of DNA. ${ }^{2}$ Since their discovery, a substantial number of biochemical and genetic studies have focused on elucidating the diverse roles of cytokinins in plant growth and, in particular, watertransport and water- stress conditions. ${ }^{3}$ Cytokinins are also involved in other essential processes such as the sink/source relationship, vascular development, chloroplast differentiation, apical dominance, and senescence. It seems that these effects result from molecular interactions with other plant hormones and environmental signals. ${ }^{4}$ Studies using structure-activity relationships have revealed the importance of the isoprenoid side chain for cytokinin activity. ${ }^{5}$ Although the effects of cytokinins in plants are well known, the mechanism of their action is still not fully understood. ${ }^{6,7}$ Moreover, $N$-6- substituted adenine derivatives show pharmacological activity in humans, have found application in molecular medicine. ${ }^{2}$ Gleditsia caspia (Leguminosae) is a perennial shrub that is found in temperate and sub-tropical North and South America, tropical Africa, and Central and Eastern Asia. In traditional Chinese medicine the genus Gleditsia is used 
in the treatment of apoplexy, as an expectorant, and for a pesticide. ${ }^{8}$ Our literature survey indicated that triterpenoidal saponins, steroids, alkaloids, and flavonoids have been isolated from the genus Gleditsia. ${ }^{9-11}$ We report here the isolation and structural characterization of three new cytokinins isolated for the first time from the natural source.
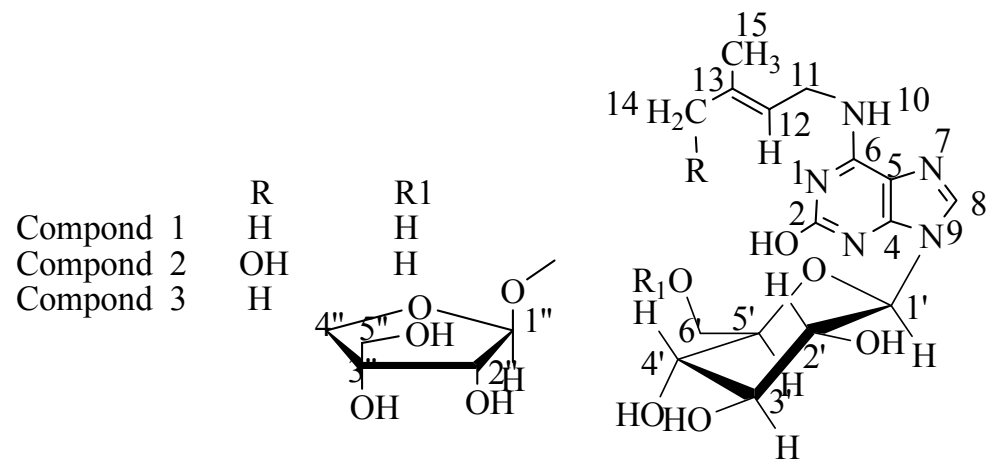

Figure 1. Structures of compounds 1, 2 and 3.

\section{Results and Discussion}

The fruits of Gleditsia caspia were extracted with ethanol and then the dried ethanolic extract was suspended in water and partitioned successively with petroleum, EtOAc, and $n-\mathrm{BuOH}$. The $n$-BuOH fraction was passed through a polyamide column. The water eluate was chromatographed over reversed-phase silica gel to yield four fractions [A-D]. Fraction A was repeatedly chromatographed over Sephadex LH-20 and silica gel to yield three cytokinins 1-3.

Compound 1, was obtained as a white amorphous powder and gave on TLC yellowish-brown color with vanillin $/ \mathrm{H}_{2} \mathrm{SO}_{4}$ reagent at $R f 0.78$ with $\mathrm{CHCl}_{3}-\mathrm{MeOH}-\mathrm{H}_{2} \mathrm{O}$ (61-32-7) as developing solvent It displayed a $[\mathrm{M}+\mathrm{H}]^{+}$ion at $\mathrm{m} / z 382.1742$ and a $[\mathrm{M}+\mathrm{Na}]^{+}$ion at $\mathrm{m} / z 404.1546$ in the positive ion HR-FAB-MS spectrum, consistent with the molecular formula $\mathrm{C}_{16} \mathrm{H}_{23} \mathrm{~N}_{5} \mathrm{O}_{6}$. Its UV spectrum showed absorption bands at 210 and $270 \mathrm{~nm}$ which are indicative of N-6- substituted adenine derivatives. ${ }^{12}$ The IR spectrum showed absorption peaks at $3440,1640 \mathrm{~cm}^{-1}$, indicating the presence of hydroxyl and conjugated $\mathrm{C}=\mathrm{N}$ groups, respectively. The presence of a hydroxyadenine skeleton was indicated from the ${ }^{1} \mathrm{H}$ - NMR spectrum by the characteristic aromatic proton singlet at $\delta 8.03$ and from the ${ }^{13} \mathrm{C}$ - and DEPT- NMR by the presence of five $\mathrm{sp}^{2}$ carbons with $\delta 102.90,143.47,153.58,153.95$ and 155.40 , corresponding to C-4, $-8,-6,-5$ and -2 , respectively, and from the presence of five nitrogen atoms as indicated from the FAB-MS. The isopentenyl side chain was indicated by an olefinic proton at $\delta 5.21(1 \mathrm{H}, b r, \mathrm{H}-12)$, geminal methylene protons at $\delta 4.48\left(2 \mathrm{H}, b r, \mathrm{H}_{2}-11\right)$ and two sharp singlets at $\delta 1.73$ and 1.58 due to two methyl protons; $\mathrm{H}_{3}-14$ and $\mathrm{H}_{3}-15$, respectively, along with one methylene carbon at $\delta 39.95$ (C11 ), one methine carbon at $\delta 120.61(\mathrm{C}-12)$, one quaternary carbon at $\delta 135.34$ (C-13) and two methyl carbons at $18.54(\mathrm{C}-14)$ and 25.94 (C-15), as shown in the ${ }^{13} \mathrm{C}$ - and ${ }^{13} \mathrm{C}$ - DEPT NMR 
spectra (Table 1). The ${ }^{1} \mathrm{H}-\mathrm{NMR}$ spectrum also showed broad signals at $\delta 4.82(1 \mathrm{H}), 5.14(1 \mathrm{H})$, $5.41(1 \mathrm{H}), 5.71(2 \mathrm{H})$ and $7.09(1 \mathrm{H})$ corresponding to $-\mathrm{OH}$ and $-\mathrm{NH}$ protons. For the assignment of the two methyl carbons in compound $\mathbf{1}$, the more deshielded signal was assigned to the one which is trans- to the amino group. ${ }^{13,14}$

Table 1. 1D- and 2D- NMR data (500 and $125.0 \mathrm{MHz}$ in DMSO- $d_{6}$ ) for compound 1

\begin{tabular}{lllll}
\hline Position & $\delta_{\mathrm{C}}$, mult. & $\delta_{\mathrm{H}}(J$ in $\mathrm{Hz})$ & $\mathrm{DQF}-\mathrm{COSY}$ & $\mathrm{HMBC}$ \\
\hline 2 & $155.40, \mathrm{q}-\mathrm{C}$ & - & - & - \\
4 & $153.95, \mathrm{q}-\mathrm{C}$ & - & - & - \\
5 & $102.90, \mathrm{q}-\mathrm{C}$ & - & - & - \\
6 & $153.58, \mathrm{q}-\mathrm{C}$ & - & - & - \\
8 & $143.47, \mathrm{CH}$ & $8.03, \mathrm{~s}$ & $\mathrm{H}-1^{\prime}$ & $\mathrm{C}-1^{\prime}, 4,5$ \\
11 & $39.95, \mathrm{CH}_{2}$ & $4.48, \mathrm{br}$ & $\mathrm{H}-12$ & $\mathrm{C}-6,12,13,15$ \\
12 & $120.61, \mathrm{CH}$ & $5.21, \mathrm{br}$ & $\mathrm{H}-11,14,15$ & $\mathrm{C}-11,13,14,15$ \\
13 & $135.34, \mathrm{q}-\mathrm{C}$ & - & - & - \\
14 & $18.54, \mathrm{CH} 3$ & $1.73, \mathrm{~s}$ & $\mathrm{H}-12$ & $\mathrm{C}-12,13,15$ \\
15 & $25.94, \mathrm{CH} 3$ & $1.58, \mathrm{~s}$ & $\mathrm{H}-12,14$ & $\mathrm{C}-12,13,14$ \\
$1^{\prime}$ & $86.85, \mathrm{CH}$ & $5.39, \mathrm{~d}(8.6)$ & $\mathrm{H}-8,2^{\prime}$ & $\mathrm{C}-4,8,2^{\prime}, 3^{\prime}, 5^{\prime}$ \\
$2^{\prime}$ & $73.05, \mathrm{CH}$ & $3.29, \mathrm{dd}, 8.6,9.0$ & $\mathrm{H}-1^{\prime}, 3^{\prime}$ & $\mathrm{C}-1^{\prime}, 3^{\prime}, 4^{\prime}$ \\
$3^{\prime}$ & $76.69, \mathrm{CH}$ & $3.34^{*}$ & $\mathrm{H}-2^{\prime}, 4^{\prime}$ & $\mathrm{C}-1^{\prime}, 2^{\prime}, 4^{\prime}, 5^{\prime}$ \\
$4^{\prime}$ & $68.36, \mathrm{CH}$ & $3.46, \mathrm{t}(9.0)$ & $\mathrm{H}-3^{\prime}, 5^{\prime}$ & $\mathrm{C}-2^{\prime}, 3^{\prime}, 5^{\prime}, 6^{\prime}$ \\
$5^{\prime}$ & $79.94, \mathrm{CH}$ & $3.53, \mathrm{~m}$ & $\mathrm{H}-4^{\prime}, 6^{\prime} \mathrm{a}, 6^{\prime} \mathrm{b}$ & $\mathrm{C}-1^{\prime}, 3^{\prime}, 4^{\prime}, 6^{\prime} \mathrm{a}, \mathrm{b}$ \\
$6^{\prime} \mathrm{a}$. & $59.28, \mathrm{CH} 2$ & $3.69, \mathrm{dd}(11.5,2.8)$ & $\mathrm{H}-5,6^{\prime} \mathrm{b}$ & $\mathrm{C}-4^{\prime}, 5^{\prime}$ \\
$6^{\prime} \mathrm{b}$. & - & $3.60, \mathrm{dd}(11.5,5.0)$ & $\mathrm{H}-5,6^{\prime} \mathrm{a}$ & $\mathrm{C}-4^{\prime}, 5^{\prime}$ \\
\hline
\end{tabular}

* The splitting pattern was masked by the water signal.

The glucose moiety was identified from the one anomeric proton and carbon resonances at $\delta_{\mathrm{H}}$ $5.39\left(\mathrm{H}-1^{\prime}\right), \delta_{\mathrm{C}} 86.85\left(\mathrm{C}-1^{\prime}\right)$ of glucose. The identity of the sugar moiety was determined by a combination of COSY, HMQC and HMBC experiments (Table 1). The $\beta$-anomeric configuration of the glucose moiety was evident from the $J-\mathrm{H} 1, \mathrm{H} 2$ value of $8.6 \mathrm{~Hz} .{ }^{15}$ The attachment of the glucose moiety to the N-6-position of the hydroxyl adenine skeleton was confirmed by the longrange correlations between $\mathrm{H}-1$ ' $(\delta 5.39)$ of glucose and the methine carbon at $\delta 143.47(\mathrm{C}-8)$ and the quaternary carbon at $\delta 153.95(\mathrm{C}-4)$, in the HMBC spectrum of $\mathbf{1}$. Therefore the structure of 1 was established to be 6- $N$-(3-methylbut-2-enylamino)-2-hydroxy-9- $\beta$-D-glucopyranosyl purine.

Compound 2, was also obtained as a white amorphous powder, and gave on TLC yellowishbrown color with vanillin $/ \mathrm{H}_{2} \mathrm{SO}_{4}$ reagent at $R f 0.56$ with $\mathrm{CHCl}_{3}-\mathrm{MeOH}-\mathrm{H}_{2} \mathrm{O}$ (61-32-7) as developing solvent. It has an $[\mathrm{M}+\mathrm{H}]^{+}$ion at $m / z=398.1694$ and $[\mathrm{M}+\mathrm{Na}]^{+}$ion at $m / z 420.1515$ in the HR FAB-MS, 16 mass units more than that of $\mathbf{1}$, suggesting the molecular formula of 2 to be 
$\mathrm{C}_{16} \mathrm{H}_{23} \mathrm{~N}_{5} \mathrm{O}_{7}$. The UV spectrum showed absorption bands at 215 and $266 \mathrm{~nm}$, and the IR spectrum showed absorption bands for hydroxyl group at 3445 and for conjugated $\mathrm{C}=\mathrm{N}$ groups at $1640 \mathrm{~cm}^{-1}$.

Table 2. 1D- and 2D- NMR data (500 and $125.0 \mathrm{MHz}$, in DMSO- $\left.d_{6}\right)$ for compound 2.

\begin{tabular}{lllll}
\hline Position & $\delta_{\mathrm{C}}$, mult. & $\delta_{\mathrm{H}}(J$ in Hz$)$ & DQF-COSY & HMBC \\
\hline 2 & $154.03, \mathrm{q}-\mathrm{C}$ & - & - & - \\
4 & $153.44, \mathrm{q}-\mathrm{C}$ & - & - & - \\
5 & $103.01, \mathrm{q}-\mathrm{C}$ & - & - & - \\
6 & $153.16, \mathrm{q}-\mathrm{C}$ & - & - & - \\
8 & $143.65, \mathrm{CH}$ & $8.08, \mathrm{~s}$ & $\mathrm{H}-1^{\prime}$ & $\mathrm{C}-1^{\prime}, 4,5$ \\
11 & $39.92, \mathrm{CH}_{2}$ & $4.55, \mathrm{~d}(7.1)$ & $\mathrm{H}-12$ & $\mathrm{C}-6,12,13,15$ \\
12 & $121.35, \mathrm{CH}$ & $5.23, \mathrm{t}(7.1)$ & $\mathrm{H}-11,14,15$ & $\mathrm{C}-11,13,14,15$ \\
13 & $139.98, \mathrm{q}-\mathrm{C}$ & - & - & - \\
14 & $60.38, \mathrm{CH} 2$ & $4.07, \mathrm{~d}(5.6)$ & $\mathrm{H}-12$ & $\mathrm{C}-12,13,15$ \\
15 & $21.88, \mathrm{CH}{ }_{3}$ & $1.64, \mathrm{~s}$ & $\mathrm{H}-12,14$ & $\mathrm{C}-12,13,14$ \\
$1^{\prime}$ & $86.92, \mathrm{CH}$ & $5.41, \mathrm{~d}(8.4)$ & $\mathrm{H}-8,2^{\prime}$ & $\mathrm{C}-4,8^{\prime}, 2^{\prime}, 3^{\prime}, 5^{\prime}$ \\
$2^{\prime}$ & $73.14, \mathrm{CH}$ & $3.32^{*}$ & $\mathrm{H}-1^{\prime}, 3^{\prime}$ & $\mathrm{C}-1^{\prime}, 3^{\prime}, 4^{\prime}$ \\
$3^{\prime}$ & $76.58, \mathrm{CH}$ & $3.34^{*}$ & $\mathrm{H}-2^{\prime}, 4^{\prime}$ & $\mathrm{C}-1^{\prime}, 2^{\prime}, 4^{\prime}, 5^{\prime}$ \\
$4^{\prime}$ & $68.27, \mathrm{CH}$ & $3.46, \mathrm{t}(9.0)$ & $\mathrm{H}-3^{\prime}, 5^{\prime}$ & $\mathrm{C}-2^{\prime}, 3^{\prime}, 5^{\prime}, 6^{\prime}$ \\
$5^{\prime}$ & $80.02, \mathrm{CH}$ & $3.50, \mathrm{~m}$ & $\mathrm{H}-4^{\prime}, 6^{\prime} \mathrm{a}, 6^{\prime} \mathrm{b}$ & $\mathrm{C}-1^{\prime}, 3^{\prime}, 4^{\prime}, 6^{\prime} \mathrm{a}, \mathrm{b}$ \\
$6^{\prime} \mathrm{a}$ & $59.50, \mathrm{CH} 2$ & $3.75, \mathrm{dd}(11.4,2.8)$ & $\mathrm{H}-5,6^{\prime} \mathrm{b}$ & $\mathrm{C}-4^{\prime}, 5^{\prime}$ \\
$6^{\prime} \mathrm{b}$ & - & $3.65, \mathrm{dd}(11.4,5.0)$ & $\mathrm{H}-5,6^{\prime} \mathrm{a}$ & $\mathrm{C}-4^{\prime}, 5^{\prime}$ \\
\hline
\end{tabular}

* The splitting pattern was masked by the water signal.

The NMR data of 2 were superimposable with those of $\mathbf{1}$, verifying a close structural relationship between 2 and 1. The difference between 2 and 1 was the presence of hydroxyl isopentenyl side chain in $\mathbf{2}$ versus the iso-pentenyl side chain in $\mathbf{1}$. This was established from the ${ }^{1} \mathrm{H}$ - NMR of 2 which indicates the presence of signals for two geminal methylene protons at $\delta 4.55\left(2 \mathrm{H}\right.$, br, $\left.\mathrm{H}_{2}-11\right)$ and $\delta 4.07\left(2 \mathrm{H}\right.$, brs, $\left.\mathrm{H}_{2}-14\right)$, a methine proton at $\delta 5.23(1 \mathrm{H}, \mathrm{br}, \mathrm{H}-12)$ and one methyl group, $\delta 1.64\left(3 \mathrm{H}, \mathrm{s}, \mathrm{H}_{3}-15\right) .{ }^{13} \mathrm{C}$ - and ${ }^{13} \mathrm{C}$ - DEPT NMR spectra confirmed the hydroxy iso-pentenyl side chain by the presence of two methylene carbon signals at $\delta 60.38$ (C$14)$ and 39.92 (C-11), one methine carbon signal at $\delta 121.35$ (C-12), one methyl signal at $\delta 21.88$ (C-15), and one quaternary carbon signal at $\delta 139.98$ (C-13). Seven broad signals at $\delta 4.87(1 \mathrm{H})$, $5.35(1 \mathrm{H}), 5.50(1 \mathrm{H}), 5.83(2 \mathrm{H})$ and $7.40(2 \mathrm{H})$ corresponding to $-\mathrm{OH}$ and $-\mathrm{NH}$ protons, were also observed in the ${ }^{1} \mathrm{H}$ - NMR of 2. Combined 2D- NMR (COSY, HMQC and HMBC) experiments determine the structure of the aglycon moiety of $\mathbf{2}$ as 2 -hydroxyzeatin (Table 2).

The ${ }^{1} \mathrm{H}$ - and ${ }^{13} \mathrm{C}$ - NMR spectra of 2 revealed the presence of one $\beta$-D-glucopyranosyl moiety from the chemical shift and $J$ value of one anomeric proton at $\delta 5.41\left(\mathrm{~d}, J=8.4 \mathrm{~Hz}, \mathrm{H}-1^{\prime}\right)$ and the 
chemical shift of one anomeric carbon at $\delta 86.92$ (C-1'). The HMBC spectrum showed crosspeaks between the glucosyl anomeric proton $\left(\delta 5.41, \mathrm{H}-1^{\prime}\right)$ and $\mathrm{C}-8$ ( $\delta$ 143.65) and C-4 $(\delta$ 153.44) and confirmed that the glucose moiety was attached to the N-6-position of the aglycon. The configuration of the iso- pentenyl group of the hydroxyzeatin was determined to be cis- by comparison of the chemical shifts of the ${ }^{1} \mathrm{H}$ - and ${ }^{13} \mathrm{C}$ - NMR signals with those of trans- zeatin riboside. $^{13,16,17}$ Consequently, the structure of 2 was determined as 6- $N$-(cis-4-hydroxy-3methylbut-2-enylamino)-2-hydroxy-9- $\beta$-D-glucopyranosyl purine 2.

Compound 3, was obtained as a white amorphous powder with molecular formula $\mathrm{C}_{21} \mathrm{H}_{31} \mathrm{~N}_{5} \mathrm{O}_{10}$ as indicated from the HR-FAB-MS ions at $m / z 514.2169[\mathrm{M}+\mathrm{H}]^{+}$and 536.1988 $[\mathrm{M}+\mathrm{Na}]^{+}$. Combined with the evidence from monosaccharide composition analysis shown in the Experimental Section, this suggested that in compound $\mathbf{3}$ an apiose moiety (132 mass units) was present in addition to the skeleton present in 1. It gave on TLC yellowish-brown color with vanillin/ $\mathrm{H}_{2} \mathrm{SO}_{4}$ reagent at $R f 0.31$ with $\mathrm{CHCl}_{3}-\mathrm{MeOH}-\mathrm{H}_{2} \mathrm{O}$ (61-32-7) as developing solvent. Its UV and IR spectra showed absorption bands similar to $\mathbf{1}$ and 2 . The ${ }^{1} \mathrm{H}-\mathrm{NMR}$ of $\mathbf{3}$ was very similar to that of $\mathbf{1}$, but had extra signals for an additional sugar moiety indicated by the signals of two anomeric protons, the usual one at $\delta 5.42(1 \mathrm{H}, \mathrm{d}, J=8.4 \mathrm{~Hz}, \mathrm{H}-1$ ' of glucose) and a second at $\delta 4.82(1 \mathrm{H}, \mathrm{d}, J=3.0 \mathrm{~Hz}, \mathrm{H}-1$ " of apiose $)$. The ${ }^{13} \mathrm{C}-\mathrm{NMR}$ spectrum of 3 also showed a signal arising from an extra anomeric carbon at $\delta 109.65$ (Table 3 ). The $\beta$-configuration on $\mathrm{C}-1$ anomeric orientation of apiose was confirmed by comparing the ${ }^{1} \mathrm{H}$ - and ${ }^{13} \mathrm{C}$ - NMR of 3 with those of $\alpha$-D- $\delta_{\mathrm{C}} 104.5$ and $\beta$-D- apiofuranosides $\delta_{\mathrm{C}} 111.5$, respectively. ${ }^{18,19}$ The signal of the glucosidic carbon, C-6' in 3 showed a typical glycosidation shift downfield by 6.6 ppm when compared to the unsubstituted C-6' of the glucose moiety in 1, supporting the attachment of the apiose moiety to the glucosyl unit at C-6'. This was confirmed by HMBC cross-peaks between the anomeric proton of apiose and $\mathrm{C}-6$ ' of glucose, and between $\mathrm{H}_{2}-6$ ' of glucose and the anomeric carbon of apiose. Furthermore, the HMBC spectrum of $\mathbf{3}$ showed correlations between the anomeric proton of the glucose and $\mathrm{C}-4$ and $\mathrm{C}-8$ of the hydroxyadenine skeleton, confirming the attachment of the disaccharide moiety to the N-6- position of the aglycon. 
Table 3. 1D- and 2D- NMR Spectroscopic Data (500 and $125.0 \mathrm{MHz}$ in DMSO- $d_{6}$ ) for compound 3

\begin{tabular}{lllll}
\hline Position & $\delta_{\mathrm{C}}$, mult. & $\delta_{\mathrm{H}}(\mathrm{J}$ in Hz$)$ & DQF-COSY & HMBC \\
\hline 2 & $155.50, \mathrm{q}-\mathrm{C}$ & - & - & - \\
4 & $153.87, \mathrm{q}-\mathrm{C}$ & - & - & - \\
5 & $102.91, \mathrm{q}-\mathrm{C}$ & - & - & - \\
6 & $153.71, \mathrm{q}-\mathrm{C}$ & - & - & - \\
8 & $143.75, \mathrm{CH}$ & $8.06, \mathrm{~s}$ & $\mathrm{H}-1^{\prime}$ & $\mathrm{C}-1^{\prime}, 4,5$ \\
11 & $39.84, \mathrm{CH} 2$ & $4.48, \mathrm{~d}(6.8)$ & $\mathrm{H}-12$ & $\mathrm{C}-6,12,13$ \\
12 & $120.45, \mathrm{CH}$ & $5.20, \mathrm{t}(6.8)$ & $\mathrm{H}-11,14,15$ & $\mathrm{C}-11,13,14,15$ \\
13 & $135.51, \mathrm{q}-\mathrm{C}$ & - & - & - \\
14 & $18.52, \mathrm{CH}$ & $1.72, \mathrm{~s}$ & $\mathrm{H}-12,15$ & $\mathrm{C}-12,13,15$ \\
15 & $25.93, \mathrm{CH}$ & $1.59, \mathrm{~s}$ & $\mathrm{H}-12,14$ & $\mathrm{C}-12,13,14$ \\
$1^{\prime}$ & $86.84, \mathrm{CH}$ & $5.42, \mathrm{~d}(8.4)$ & $\mathrm{H}-8,2^{\prime}$ & $\mathrm{C}-4,8,2^{\prime}, 3^{\prime}, 5^{\prime}$ \\
$2^{\prime}$ & $72.96, \mathrm{CH}$ & $3.34 *$ & $\mathrm{H}-1^{\prime}, 3^{\prime}$ & $\mathrm{C}-1^{\prime}, 3^{\prime}, 4^{\prime}$ \\
$3^{\prime}$ & $76.66, \mathrm{CH}$ & $3.30, \mathrm{t}, 9.0$ & $\mathrm{H}-2^{\prime}, 4^{\prime}$ & $\mathrm{C}-1^{\prime}, 2^{\prime}, 4^{\prime}, 5^{\prime}$ \\
$4^{\prime}$ & $68.58, \mathrm{CH}$ & $3.45, \mathrm{t}(9.0)$ & $\mathrm{H}-3^{\prime}, 5^{\prime}$ & $\mathrm{C}-2^{\prime}, 3^{\prime}, 5^{\prime}, 6^{\prime}$ \\
$5^{\prime}$ & $78.22, \mathrm{CH}$ & $3.65, \mathrm{~m}$ & $\mathrm{H}-4^{\prime}, 6^{\prime} \mathrm{a}, 6^{\prime} \mathrm{b}$ & $\mathrm{C}-1^{\prime}, 3^{\prime}, 4^{\prime}, 6^{\prime} \mathrm{a}, \mathrm{b}$ \\
$6^{\prime} \mathrm{a}$ & $65.92, \mathrm{CH} 2$ & $3.81, \mathrm{dd}(11.5,2.8)$ & $\mathrm{H}-5,6^{\prime} \mathrm{b}$ & $\mathrm{C}-4^{\prime}, 5^{\prime}$ \\
$6^{\prime} \mathrm{b}$ & - & $3.67, \mathrm{dd}(11.5,5.5)$ & $\mathrm{H}-5,6^{\prime} \mathrm{a}$ & $\mathrm{C}-4^{\prime}, 5^{\prime}, 1^{\prime \prime}$ \\
$1^{\prime \prime}$ & $109.65, \mathrm{CH}$ & $4.82, \mathrm{~d}(3.0)$ & $\mathrm{H}-2^{\prime \prime}$ & $\mathrm{C}-6^{\prime}, 2^{\prime \prime}, 3^{\prime \prime}, 4^{\prime \prime}$ \\
$2^{\prime \prime}$ & $76.58, \mathrm{CH}$ & $3.83, \mathrm{~d}(3.1)$ & $\mathrm{H}-1^{\prime \prime}$ & $\mathrm{C}-1^{\prime \prime}, 3^{\prime \prime}, 4^{\prime \prime}$ \\
$3^{\prime \prime}$ & $79.22, \mathrm{q}-\mathrm{C}$ & - & - & - \\
$4^{\prime \prime} \mathrm{a}$ & $73.72, \mathrm{CH} \mathrm{H}_{2}$ & $3.85, \mathrm{~d}, 9.3$ & $\mathrm{H}-4^{\prime \prime} \mathrm{b}$ & $\mathrm{C}-2^{\prime \prime}, 3^{\prime \prime}, 5^{\prime \prime}$ \\
$4^{\prime \prime} \mathrm{b}$ & - & $3.59, \mathrm{~d}, 9.3$ & $\mathrm{H}-4^{\prime \prime} \mathrm{a}$ & $1^{\prime \prime}$ \\
$5^{\prime \prime} \mathrm{a}$. & $62.90, \mathrm{CH}_{2}$ & $3.40, \mathrm{~d}(11.5)$ & $\mathrm{H}-5^{\prime \prime} \mathrm{b}$ & $\mathrm{C}-2^{\prime \prime}, 3^{\prime \prime}, 4^{\prime \prime}$ \\
$5^{\prime \prime} \mathrm{b}$. & - & $3.31, \mathrm{~d}(11.5)$ & $\mathrm{H}-5^{\prime \prime} \mathrm{a}$ & $\mathrm{C}-2^{\prime \prime}, 3^{\prime \prime}, 4^{\prime \prime}$ \\
\hline
\end{tabular}

* The splitting pattern was masked by the water signal.

The ${ }^{1} \mathrm{H}$ - NMR spectrum of $\mathbf{3}$ also showed eight broad signals for $-\mathrm{OH}$ and $-\mathrm{NH}$ protons at $\delta$ $4.08(1 \mathrm{H}), 4.17(1 \mathrm{H}), 4.63(1 \mathrm{H}), 5.14(1 \mathrm{H}), 5.51(3 \mathrm{H})$, and $7.19(1 \mathrm{H})$. Based on the above evidence, compound 3 was established to be 6- $N$-(3-methylbut-2-enylamino)-2-hydroxy-9-[ $\beta$-Dapiofuranosyl-(1" $\rightarrow 6$ ')- $\beta$-D-glucopyranosyl] purine.

\section{Experimental Section}

General. Melting points were obtained on a Stuart SMP3 apparatus. UV spectra were determined with a Hitachi 340 spectrophotometer, IR spectra from a Nicolet 205 FT-IR 
spectrometer connected to a Hewlett-Packard Color Pro. Plotter. The ${ }^{1} \mathrm{H}-$ and ${ }^{13} \mathrm{C}-\mathrm{NMR}$ measurements were obtained with a Jeol JNM ECA 500 spectrometer operating at $500 \mathrm{MHz}$ (for ${ }^{1} \mathrm{H}-$ ) and $125 \mathrm{MHz}$ (for ${ }^{13} \mathrm{C}$-) in DMSO- $d_{6}$ solution, and chemical shifts are expressed in $\delta$ (ppm) with reference to TMS, and coupling constants $(J)$ in Hertz. The ${ }^{13} \mathrm{C}$ - multiplicities were determined by the DEPT pulse sequence $\left(135^{\circ}\right)$. COSY, HMBC and HMQC- NMR experiments were carried out using a Jeol JNM ECA-500 high field spectrometer. HR- FAB MS were taken on a VGZAB-HF reversed geometry mass spectrometer (BE configuration, where " $\mathrm{B}$ " is a magnetic sector and "E" is an electrostatic analyzer). Polyamide (ICN Biomedicals), and silica gel ( $\mathrm{Si}$ gel 60, Merck), were used for open column chromatography. Flash column liquid chromatography was performed using J.T. Baker glassware with $40 \mu \mathrm{m}$ Si gel (Baker) and Sepralyte $\mathrm{C}_{18}(40 \mu \mathrm{m})$ as stationary phases. TLC was performed on precoated silica gel $60 \mathrm{~F}_{254}$ (Merck) plates. Developed chromatograms were visualized by spraying with $1 \%$ vanillin- $\mathrm{H}_{2} \mathrm{SO}_{4}$, followed by heating at $100{ }^{\circ} \mathrm{C}$ for $5 \mathrm{~min}$ or spraying the developed plates with $2 \%$ ninhydrin in acetone.

\section{Plant material}

The fruits of G. caspia Desf. were collected from the Al-Orman garden, Giza, Egypt in April 2002. The plant material was identified by the late Professor Nabil El-Hadidy (Faculty of Science, Cairo University, Egypt). A voucher specimen $\{\mathrm{f} 202\}$ has been deposited in the Museum of the Pharmacognosy Department, Faculty of Pharmacy, Al-Azhar University, Cairo, Egypt.

Extraction and isolation. The powdered fruits $(2.25 \mathrm{Kg})$ of $G$. caspia were subjected to exhaustive extraction with $95 \% \mathrm{EtOH}(4 \times 8 \mathrm{~L})$. The alcoholic extract was dried $(205 \mathrm{~g})$, and suspended in $\mathrm{H}_{2} \mathrm{O}(400 \mathrm{ml})$, and then partitioned successively with light petroleum $(10.0 \mathrm{~g})$, EtOAc $(8.2 \mathrm{~g})$ and $n-\mathrm{BuOH}(34.0 \mathrm{~g})$. The $n-\mathrm{BuOH}-$ soluble fraction was applied to a column of Polyamide and washed with $\mathrm{H}_{2} \mathrm{O}$ and $25,50,75$, and $100 \% \mathrm{MeOH}$. The water fraction was rechromatographed over a Sepralyte $\mathrm{C}_{18}$ - flash column to give four fractions, of $\mathrm{A}, \mathrm{B}, \mathrm{C}$ and $\mathrm{D}$. Fraction A (160 mg) was repeatedly applied to Sephadex $\mathrm{LH} 20 \mathrm{CC}$ using $\mathrm{CHCl}_{3}-\mathrm{MeOH}(50: 50)$ and $\mathrm{MeOH}, 100 \%$, to gave two fractions $\mathrm{A} 1$ and $\mathrm{A} 2$. Fractions $\mathrm{A} 1$ and $\mathrm{A} 2$ were subjected separately to silica- gel CC, eluted with $\mathrm{CHCl}_{3}-\mathrm{MeOH}$ (90:10-80:20) and further purification with Sephadex LH $20 \mathrm{CC}$ using $\mathrm{MeOH}$ to afford compound 2 ( $15 \mathrm{mg}$ ) from fraction A1 and compounds $\mathbf{1}$ ( $20 \mathrm{mg}$ ) and $\mathbf{3}$ ( $37 \mathrm{mg}$ ) from fraction A2.

Compound 1. White amorphous powder from $\mathrm{MeOH}, \mathrm{mp} 177-179{ }^{\circ} \mathrm{C}, R_{f} 0.78\left(\mathrm{CHCl}_{3}-\mathrm{MeOH}-\right.$ $\left.\mathrm{H}_{2} \mathrm{O}, 61: 32: 7\right)$, UV (MeOH), $\lambda_{\max }$ ): $210,270 \mathrm{~nm}$; IR (KBr) 3440, $1640 \mathrm{~cm}^{-1} ;{ }^{1} \mathrm{H}-$ and ${ }^{13} \mathrm{C}-\mathrm{NMR}$ data are shown in Table 1; HR-FAB-MS $m / z 382.1742[\mathrm{M}+\mathrm{H}]^{+}$(Calcd for 382.1727), 404.1563 $[\mathrm{M}+\mathrm{Na}]^{+}$(Calcd for $\mathrm{C}_{16} \mathrm{H}_{23} \mathrm{~N}_{5} \mathrm{O}_{6}$ ).

Compound 2. White amorphous powder from $\mathrm{MeOH}, \mathrm{mp} 175-177{ }^{\circ} \mathrm{C}, R_{f}, 0.56\left(\mathrm{CHCl}_{3}-\mathrm{MeOH}-\right.$ $\left.\mathrm{H}_{2} \mathrm{O}, 61: 32: 7\right)$, UV (MeOH, $\lambda_{\max }, 215,266 \mathrm{~nm}$, IR (KBr): 3445, $1640 \mathrm{~cm}^{-1} .{ }^{1} \mathrm{H}-$ and ${ }^{13} \mathrm{C}-\mathrm{NMR}$ data are shown in Table 2 HR-FAB-MS $m / z 398.1694[\mathrm{M}+\mathrm{H}]^{+}$(Calcd for 398.1676), 420.1515 $[\mathrm{M}+\mathrm{Na}]^{+}$(Calcd for $\mathrm{C}_{16} \mathrm{H}_{23} \mathrm{~N}_{5} \mathrm{O}_{7}$ ). 
Compound 3. White amorphous powder from $\mathrm{MeOH}, \mathrm{mp} 191-193{ }^{\circ} \mathrm{C}, R_{f} ; 0.31\left(\mathrm{CHCl}_{3}-\mathrm{MeOH}-\right.$ $\mathrm{H}_{2} \mathrm{O}$, 61:32:7), UV (MeOH, $\left.\lambda_{\text {max. }}\right) \quad 215,270 \mathrm{~nm}$. IR $(\mathrm{KBr}): 3445,1640 \mathrm{~cm}^{-1}$. ${ }^{1} \mathrm{H}$ - and ${ }^{13} \mathrm{C}$ - NMR data are shown in Table 3 HR-FAB-MS $m / z 514.2169[\mathrm{M}+\mathrm{H}]{ }^{+}(\mathrm{Calcd}$ for 514.2149), $536.1988[\mathrm{M}+\mathrm{Na}]^{+}$(Calcd for $\mathrm{C}_{21} \mathrm{H}_{31} \mathrm{~N}_{5} \mathrm{O}_{10}$ ).

Acid hydrolysis of compounds 1, 2 and $3 .^{20}$ Samples $(5 \mathrm{mg})$ of 1,2 and 3 were separately hydrolyzed with $0.1 \mathrm{~N} \mathrm{H}_{2} \mathrm{SO}_{4}(1.0 \mathrm{ml})$ at $100^{\circ} \mathrm{C}$ for 2 hours. After neutralization with $\mathrm{NaHCO}_{3}$, the solvent was evaporated. The water-soluble part of the residue showed a spot at the same $R_{f}$ as glucose for $\mathbf{1}$ and 2, and glucose and apiose for 3, on TLC (silica gel 14:6:1 $\mathrm{CHCl}_{3}-\mathrm{MeOH}-\mathrm{H}_{2} \mathrm{O}$ ).

\section{Acknowledgements}

Thanks are due to Prof. John P. N. Rosazza, Head, Division of Medicinal and Natural Products Chemistry and Director of the Center for Biocatalysis and Bioprocessing, College of Pharmacy, University of Iowa, Iowa City, IA 52242 USA, for mass- and NMR- analysis of compound $\mathbf{1 .}$

\section{References}

1. Mok, D. W.; Mok, M. C.; Cytokinins: Chemistry, Activity and Function. CRC Press: Boca Raton, FL 1994.

2. Barciszewski, J.; Massino, F.; Clark, B. F. Int. J. Biol. Macromol. 2007, 40, 182.

3. Pospisilova, J.; Synkova, H.; Rulcova, J. Biol. Plantarum 2000, 43, 321.

4. Mok, D. W.; Mok, M. C. Ann. Rev. Plant Physiol. Plant Mol. Biol. 2001, 89, 89.

5. Skoog, F.; Armstrong D. J. Ann. Rev. Plant Physiol. 1970, 21, 359.

6. Chow, B.; McCourt, P. Genes Dev. 2006, 20, 1998.

7. Hutchinson, C. E.,; Li, J.; Argueso, C.; Gonzalez, M.; Lee, E.; Lewis, M. W.; Maxwell, B. B.; Perdue, T. D.; Schalle, G. E.; Alomso, J. M.; Ecker, J. R.; Kieber, J. J. Plant Cell 2006, $18,3073$.

8. Zhong, Y.; Dian, D. C. Jiangsu New Medical College. Shanghai People's Public Health Publishing House: Shanghai, 1977, 1144-1147, 2198.

9. Zhang, Z.; Koike, K.; Jia, Z.; Nikaido, T.; Guo, D.; Zheng, J. J. Nat. Prod. 1999, 62, 877.

10. Lim, J. C.; Park, J.; Budesinsky, M.; Kasal, A.; Han, Y. H.; Koo, B. S.; Lee, S.; Lee, D. U. Chem. Pharm. Bull. 2005, 53, 561.

11. Yoshizaki, M.; Tomimori, T.; Namba, T. Chem. Pharm. Bull. 1977, 25, 3408.

12. Leonard, N. J.; Deyrup, J. A. J. Am. Chem. Soc. 1962, 84, 2148.

13. Chen, S. C.; Cyr, N. Agric. Biol. Chem. 1982, 46, 2361.

14. Stothers, J. B. Carbon-13 NMR Spectroscopy. Academic Press: New York, 1972, p 80.

15. Altona, C.; Haasnoot, C. A. Org. Magn. Reson. 1980, 13, 417. 
16. Kobayashi, H.; Morisaki, N.; Tago, Y.; Hashimoto, Y.; Iwasaki, S.; Kawashi, E.; Nagata, R.; Shodu, K. Chem. Pharm. Bull. 1997, 45, 260.

17. Kobayashi, H.; Morisaki, N.; Tago, Y.; Hashimoto, Y. Iwasaki, S.; Kawashi, E.; Nagata, R.; Shodu, K. Experientia 1995, 51, 1081.

18. Kitagawa, I.; Hori, K.; Sakagami, M.; Hashiuchi, F.; Yoshikawa, M.; Ren, J. Chem. Pharm. Bull. 1993, 41, 1350.

19. Colquhoun, I. J.; Morris, V. J.; Sutherland, I. W. Carbohydr. Res. 1989, 187, 103.

20. Lanzetta, R.; Parrilli, M.; Adinolfi, M.; Aquila, T.; Corsaro, M. M. Tetrahedron 1990, 46, 1287. 